\title{
Tectonic rift 'may threaten' Lesotho dam
}

Cape Town. Controversy is raging in South Africa about a series of earthquakes that have taken place at a new dam in Lesotho since it started to be filled last October. A prominent geologist is claiming that the dam may be more dangerous than the government accepts, as it may lie on an incipient boundary between two tectonic plates.

The Katse dam forms part of the Lesotho Highlands Water Project, a joint venture between Lesotho and South Africa, planned to provide both hydro-electricity and water for the two countries.

The largest of nine seismic events, with a magnitude $(M)$ of 2.5 on the Richter scale, was recorded on 3 January. A crack subsequently appeared stretching from the edge of the reservoir through the village of Ha Mapeleng to a 2,350-metre peak above it. The fracture is now $1.5 \mathrm{~km}$ long, and wide enough to insert a broom-handle.

With a height of 185 metres, the Katse dam will ultimately hold back about two billion tonnes of water, a load which, according to one model, will depress the surface of the Earth by about $3 \mathrm{~cm}$ over an oval-shaped area about $6 \mathrm{~km}$ upstream of the dam wall, near Ha Mapeleng.

The possibility of dam-induced seismic activity was pointed out by the original impact assessment for the project, carried out in 1988. The Geological Survey, now the Council for Geosciences, was commissioned to maintain three seismographic stations in Lesotho to monitor the situation. But the recent seismic activity has triggered a sharp debate between Chris Hartnady, professor of geology at the University of Cape Town, and the South African Department of Water Affairs and Forestry, which is responsible for the South African side of the project.

The disagreement focuses on the maximum size of an earthquake likely to occur at Katse. The dam has been built to withstand an $m 6.5$ earthquake. But Hartnady, suggesting that the entire area may lie in an intermediate zone between two plates of the Earth's lithosphere, claims that it should be required to withstand up to M7.2.

The East African Rift valley - a zone running from the Jordan River through Africa to the Zambezi - where the African continent is being extended, is widely thought of as representing the early stages of the break-up of Africa into two smaller plates. In 1990, two years after the initial impact assessment for the dam was carried out, Hartnady published an article in the South African Journal of Geology speculating that this incipient plate boundary might extend south into the Natal/KwazuluLesotho-Free State area.

If such speculation proves correct, the dam site would lie not at a seismically stable position inside a single plate, but within a wide boundary zone between the Nubian and Somalian plates (see figure, below).

The seismicity associated with this postulated East African Rift propagation is well known: the two largest African earthquakes this century were the Rukwa event in Tanzania in 1910, and the Juba event of 1990 in the Sudan with magnitudes of 7.3 and 7.2 respectively.

The official calculation that the maximum likely earthquake in the Katse dam

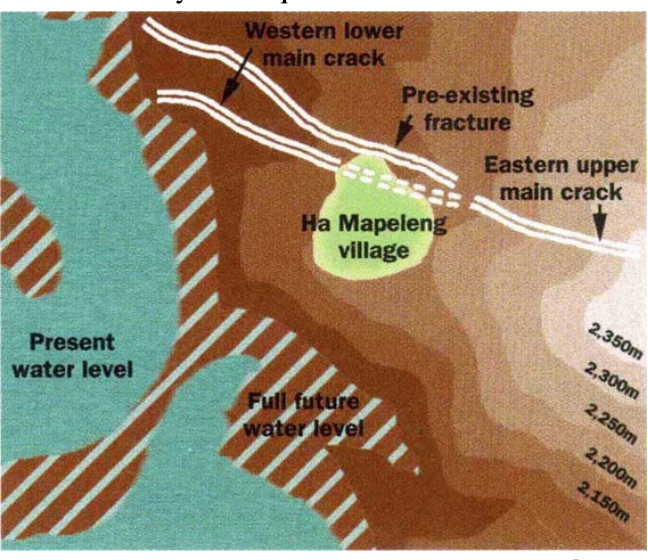

The Katse dam lies on what may be an extension of an incipient boundary between two tectonic plates.

region would be $M 6.5$ is based on plotting the frequency of earthquake occurrence and magnitude over time. But Hartnady claims that this is "tantamount to assuming that the largest earthquake that has occurred within the relatively short interval of instrumental recording is roughly equivalent in size to the largest earthquake that can be expected in the future".

Hartnady says there is an urgent need for a tectonic assessment of the crustal stress. A realistic seismotectonic model, incorporating Nubian-Somalian plate-kinematic constraints and earthquake experience from similar zones elsewhere in the East African Rift System suggests, he claims, that the size of the maximum credible earthquake in the Katse area is not less than M7.2.

"Contrary to the previous perception of material homogeneity, the Earth's crust between and around the Katse reservoir contains a wide variety of structural discontinuities which are susceptible to neotectonic reactivation in the modern crustal stress field," says Hartnady. "This could provide a focus for reservoir-triggered earthquakes."

Willie Croucamp, the managing engineer responsible for international projects at the department, disagrees. He points out that Hartnady is invoking the idea of a wide boundary zone because of uncertainty as to whether the Rift valley extends into South Africa or not.

But Croucamp says the uncertainty about Hartnady's own theory means that it cannot be used for seismic risk assessment, emphasizing that the value of $M 6.5$ was calculated according to guidelines laid down by the
International Commission on Large Dams.

Two seismic disasters in the vicinity of reservoirs have occurred in the past 30 years, both in India. In 1967, a reservoirinduced earthquake measuring $M 6.5$ at the Koyna Dam, located in a previously aseismic region, killed 177 people and injured 2,300 others. In 1993, an M6.2 earthquake, concentrated between 10 and $20 \mathrm{~km}$ from a reservoir near the town of Khillari, resulted in almost 10,000 deaths and 30,000 injuries - although it has not been proved that the earthquake was triggered by the construction of the reservoir.

A report on the recent seismic events commissioned from two outside experts by the Lesotho Highlands Development Authority, and released at the end of February, says that there is no evidence associated either with the observed cracks or with the surrounding geological features to suggest that the village or any large rock mass near the reservoir is in danger of sliding into it. (The latter is what happened at Vaiont in Italy in 1963, when a 300-milliontonne avalanche fell into the reservoir, producing a towering wave that killed nearly 2,000 people.)

The report predicts that shallow earthquakes, even of the order of $M 4.5$, could continue as the dam is filled, and recommends rehousing the villagers in earthquake-resistant houses - some of the villagers' huts have already been damaged. But the report supports the original 1988 assessment that the maximum likely earthquake at Katse is M6.5. "There is no evidence from the activity that has occurred [to] suggest that a deep-seated earthquake is imminent," the report concludes.

Nevertheless, the department has invited Hartnady to set out his views in a formal submission, and has agreed that his evidence and claims should be reviewed by a panel of experts, a process likely to take two months.

The local villagers, meanwhile, have an alternative explanation for the earthquakes at Katse. They believe the tremors are a manifestation of the wrath of the river serpent, which has been confined by the dam and is now unable to move up and down the length of the river.

Michael Cherry

\section{Einstein fails to sell}

New York. Albert Einstein's original 72page manuscript that set out to unify mass and energy failed to sell at an auction in New York last week. The highest bid - $\$ 3.3$ million - is said to have fallen short of the manuscript's minimum asking price. The auction house selling the manuscript, Sotheby's, had previously suggested that the document, which illustrates how Einstein developed some of his key ideas, could fetch up to \$6 million. 